\title{
GAGASAN PENGEMBANGAN PENDIDIKAN PESANTREN BERBASIS MARITIM DI BANTEN
}

\section{IDEAS DEVELOPMENT OF PESANTREN EDUCATION MARITIME BASED IN BANTEN}

\author{
Muhamad Murtadlo \\ Puslibang Pendidikan Agama dan Keagamaan, Balitbang dan Diklat Kementerian Agama RI \\ e-mail: murtadlo@kemenag.go.id
}

Naskah Diterima: 16 Oktober 2019; Direvisi: 19 Maret 2020; Disetujui: 02 April 2020

\begin{abstract}
Indonesia as an archipelagic country has the extraordinary potential marine wealth. It's just that, maritime culture in the nation's community has faded and is more oriented to land development (agrarian). This paper will examine the response of the pesantren world to the idea of developing a maritime spirit in supporting the idea of Indonesia as the world's maritime axis. Research questions were formulated to answer how understanding of maritime concepts was constructed and implemented by the pesantren community. This research is a qualitative research, by taking a case in pesantren bisnis.com Istana Mulia Serang Banten. From this case, the study concluded that pesantren did not have a clear concept in initiating maritime-based religious education. Various problems still hamper pesantren in building maritime culture such as related to technology and information systems, facilities and infrastructure, human resources. New strategies are needed in targeting pesantren for the formation of a maritime pesantren model. The government through the Ministry of Religion needs to make many breakthroughs to further socialize and start educational development related to maritime affairs.
\end{abstract}

Keywords: Banten; Maritime; Pesantren; Religious education

\begin{abstract}
Abstrak
Indonesia sebagai negara kepulauan mempunyai potensi kekayaan laut yang luar biasa. Hanya saja, budaya maritim pada masyarakat bangsa ini pernah meredup dan lebih berorientasi pada pembangunan daratan (agraris). Tulisan ini akan mengkaji respons dunia pesantren terhadap gagasan pembangunan semangat maritim dalam mendukung terciptanya Indonesia sebagai poros maritim dunia. Pertanyaan penelitian dirumuskan untuk menjawab bagaimana pemahaman konsep maritim dikonstruksi dan diimplementasikan oleh masyarakat pesantren. Penelitian ini termasuk penelitian kualitatif, dengan mengambil kasus di pesantren bisnis.com Istana Mulia Serang Banten. Dari kasus ini, penelitian menyimpulkan bahwa pesantren belum mempunyai konsep yang jelas dalam menggagas pendidikan keagamaan berbasis maritim. Berbagai permasalahan masih menjadi hambatan pesantren dalam membangun budaya maritim seperti terkait sistem teknologi dan informasi, sarana dan prasarana, sumber daya manusia. Perlu strategi baru dalam membidik pesantren untuk pembentukan model pesantren maritim. Pemerintah melalui Kementerian Agama perlu melakukan banyak terobosan untuk lebih mensosialisasi dan memulai pembangunan pendidikan terkait dengan kemaritiman.
\end{abstract}

Kata Kunci: Banten; Maritim; Pesantren; Pendidikan keagamaan 


\section{PENDAHULUAN}

Wacana Indonesia sebagai poros maritim disampaikan pertama kali oleh Jokowi di musim kampanye presiden tahun 2014. Setelah menjadi Presiden, Jokowi mengulangi gagasan itu dalam KTT APEC di Beijing dan KTT G20 di Sydney. Saat itu Presiden Joko Widodo menyatakan perlunya investasi besarbesaran di Indonesia untuk mendukung program Poros Maritim Dunia. Gagasan ini mengimbangi gagasan-gagasan negara-negara besar seperti Jepang dan India yang telah lebih dulu mencanangkan konsep Confluence of the Two Seas pada tahun 2007, disusul Amerika Serikat dengan Rebalancing toward Asia pada tahun 2011, dan Tiongkok dengan Jalur Sutra Maritim Abad ke-21 di tahun 2013 (Yani and Montratama, 2015).

Indonesia dengan peta wilayah mempunyai sejarah sebagai bangsa maritim. Anthony Reid menyatakan Indonesia masa lampau pernah mengalami satu era peradaban maritim yang sangat besar. Era ini bukan hanya terjadi pada Indonesia, tetapi membentang hampir di seluruh wilayah Asia Tenggara pada abad ke-15 sampai 17(Reid, 2011).

Terdapat paling tidak dua aspek yang mendukung bahwa kebijakan pemerintah tentang Poros Maritim Dunia itu dikumandangkan pada momentum yang tepat. Pertama, letak geografis Indonesia yang terletak di antara dua benua dan dua samudera yang dilalui oleh jalurjalur utama perdagangan Sea Lanes of Trade (SLOT) internasional. Jalur-jalur perdagangan ini memiliki peran yang sangat vital tidak hanya bagi negara-negara di kawasan Asia Pasifik tetapi juga memiliki arti yang sangat penting bagi negara-negara di kawasan Eropa, Timur Tengah, maupun Amerika. Hal ini dapat dimanfaatkan untuk dapat memberikan keuntungan secara politik dan ekonomi kepentingan nasional Indonesia juga dapat dimanfaatkan untuk meningkatkan posisi tawar Indonesia dimata dunia. Kedua adalah kondisi geografis Indonesia sebagai negara kepulauan terbesar di dunia dengan potensi kekayaan sumber daya kelautan yang berlimpah yang belum dimanfaatkan secara optimal untuk menyejahterakan rakyat secara keseluruhan. Dalam konsep negara kepulauan, laut berperan sebagai penghubung antar pulau, bukan pemisah. Oleh karena itu, dibutuhkan suatu kebijakan dan tindakan nyata yang dapat mewujudkan bahwa laut adalah benar-benar berperan sebagai penghubung pulau-pulau di wilayah nusantara.

Menindaklanjuti gagasan pengembangan Indonesia sebagai poros maritim ini, telah lahir Undang-undang yang mendukung usaha itu, UU No. 32 Tahun 2014. Dalam UU disebutkan bahwa Penyelenggaraan Kelautan bertujuan untuk: a. menegaskan Indonesia sebagai negara kepulauan berciri nusantara dan maritim; b. mendayagunakan Sumber Daya Kelautan dan/atau kegiatan di wilayah laut sesuai dengan ketentuan peraturan perundang-undangan dan hukum laut internasional demi tercapainya kemakmuran bangsa dan negara; c. Mewujudkan Laut yang lestari serta aman sebagai ruang hidup dan ruang juang bangsa Indonesia; d. memanfaatkan Sumber Daya Kelautan secara berkelanjutan untuk sebesar-besarnya kesejahteraan bagi generasi sekarang tanpa mengorbankan kepentingan generasi mendatang; e. memajukan budaya dan pengetahuan Kelautan bagi masyarakat; f. mengembangkan sumber daya manusia di bidang Kelautan yang profesional, beretika, berdedikasi, dan mampu mengedepankan kepentingan nasional dalam mendukung Pembangunan Kelautan secara optimal dan terpadu; g. memberikan kepastian hukum dan manfaat bagi seluruh masyarakat sebagai negara kepulauan; dan h. mengembangkan peran Negara Kesatuan Republik Indonesia dalam percaturan Kelautan global sesuai dengan hukum laut internasional untuk kepentingan bangsa dan negara.

Kementerian Agama RI, yang mempunyai tugas dan fungsi membantu pemerintah dalam pembangunan bidang agama, merespons gagasan pembangunan maritim ini. Di mulai tahun 2015, Kementerian Agama pusat telah mulai berpartisipasi dengan keterlibatannya dalam Sail Tomini 2015. Saat itu Kementerian Agama telah mengalokasikan anggaran kurang lebih 3 Milyar untuk mengadakan diskusi dan pembahasan mengenai peran pendidikan agama yang di bawah pembinaan dalam pembangunan maritim. Saat ini Kementerian Agama telah menerima usulan 360 pesantren yang mengajukan diri untuk dibina menjadi 
pesantren maritim. Ke-360 tersebut berasal dari 20 provinsi di Indonesia. Namun, nantinya program pesantren maritim ini akan dilakukan di seluruh Indonesia. Dari Aceh hingga Papua (Republika.co.id, 2015).

Sejak berpartisipasi dalam Sail Tomini 2015, sejak itu pula wacana pesantren maritim dimulai. Namun permasalahannya, seperti apa konsep pesantren maritim itu. Ketika penulis mencoba menyusuri informasi dan pidatopidato pejabat Kementerian Agama, nampak belum ada konsep yang utuh dan jelas mendeskripsikan pesantren maritim. Dalam konteks ini, mencoba mengeksplorasi gagasan dan konsep mengenai pesantren maritim.

Pertanyaan penelitian dirumuskan: bagaimana gagasan, respons dan implementasi pengembangan pendidikan keagamaan berbasis maritim di pesantren di wilayah Banten? Pertanyaan diperjelas dengan pertanyaan rincian bagaimana tradisi kemaritiman dalam sejarah Banten? Dan bagaimana respons pesantren di Banten terhadap gagasan pesantren maritim?.

\section{KAJIAN PUSTAKA}

Kajian mengenai pengembangan budaya maritim ini belum banyak, apalagi dikaitkan dengan peran lembaga pendidikan pesantren. Terkait dengan pembangunan maritim yang juga terkait dengan partisipasi pendidikan salah satu yang bisa disebut misalnya Tide Aji Pratama menyebutkan bahwa isu-isu terkait keamanan maritim tidak melulu terkait dengan politik antar negara dalam artian state security, tetapi juga human security, khususnya terkait dengan ancaman asimetris, yaitu terorisme, imigran ilegal, penyeludupan narkotika, penangkapan ikan ilegal dan perdagangan manusia. Sehingga tugas untuk menjaga keamanan laut kita membutuhkan kerja sama antar instansi di dalam negeri yang solid berdasarkan pemahaman akan perkembangan isu-isu keamanan maritim tersebut (Pratama, 2015)

Nainggolan (2015) menyebutkan
dengan menghidupkan kembali budaya
maritim, bangsa Indonesia diharapkan sudah
harus meninggalkan budaya lama kontinental-
nya yang berorientasi ke darat, agar dapat
menjadi sebuah negara bahari, seperti dalam
masa Majapahit dan Sriwijaya. Hanya dengan

kehadiran kultur ini pula, Indonesia baru bisa menjadi sebuah kekuatan laut. Sedangkan, dengan komponen ekonomi maritim, Indonesia dapat membangun basis ekonomi rakyatnya di sepanjang jalur pelayaran internasional, dengan kehadiran pelabuhan-pelabuhan bertaraf internasional dan keterhubungan mereka dengan pelabuhan-pelabuhan tradisional yang sudah ada sebelumnya di masa kolonialisme. Sebagai konsekuensinya, kebijakan Poros Maritim Dunia yang diimplementasikan Presiden Joko Widodo tidak dapat dipisahkan dari doktrin Trisakti Presiden Sukarno, yakni kemandirian di bidang politik, ekonomi, dan sosial-budaya.

Anggraeni menyebutkan dengan mengembalikan kejayaan laut akan dapat menjadi negara ini berdaya saing serta memiliki produktivitas yang tinggi. Adapun strategi dan kebijakan yang akan dilakukan oleh presiden Joko Widodo sesuai dengan visi- misinya, yaitu (1) Menerapkan paradigma baru yakni termasuk di dalamnya adalah ocean based development; (2) Memiliki strategi yang meliputi penguatan konektivitas dan peningkatan pertahanan keamanan laut Indonesia; (3) Kebijakan terkait pembangunan infrastruktur; (4) Kebijakan peningkatan keamanan laut terkait dengan illegal fishing (Anggraeni, 2016). Gagasan pengembangan pesantren dalam konteks budaya maritim merupakan konsekuensi paradigma ocean based development.

Dari aspek pembangunan terkait kemaritiman, Kerajaan Demak tempo dulu pernah merintis menjadi pemerintahan maritim. Ada dua faktor kemajuan berbasis maritim. pertama, faktor maritim yang didukung oleh faktor agraris yang bisa diandalkan. Kedua, faktor agama yang telah diajarkan oleh para wali. Para wali ini selain berdakwah, juga berperan sebagai penasihat kerajaan, karena beliau selain ahli di bidang agama juga piawai di bidang yang lain seperti bidang politik, sosial, ekonomi, budaya, seni, kesehatan, dan lainnya. Warisan-warisan negara tradisional itu sampai sekarang masih eksis di nusantara. Penulis menduga yang menjadi faktor kendala utama pengembangan budaya maritim di Indonesia, salah satunya belum tersedianya sumber daya manusia yang memiliki kompetensi kelautan yang memadai. Sehingga 
dengan kekayaan alam di laut yang banyak ini, Indonesia belum bisa mengolah serta memanfaatkan secara optimal. Selain itu, banyaknya tindakan kriminal di sekitar ekonomi pelabuhan membawa dampak negatif serta turunnya supremasi Indonesia atas lautan (Pianto, 2017).

Faktor penyebab hilangnya semangat maritim, Yuliati menyebutkan bahwa datangnya orang Eropa, terutama bangsa Belanda mencoba menguasai bumi Nusantara, para penguasa diikat melalui sejumlah perjanjian yang menghilangkan daerah pantai. Daerah pantai menjadi milik bangsa Belanda. Dampak yang timbul adalah lama kelamaan jiwa bahari yang dimiliki bangsa Indonesia mulai hilang. Bangsa Indonesia adalah bangsa yang dikelilingi lautan, namun bukan bangsa yang memiliki laut, karena laut telah menjadi milik bangsa Belanda (Yuliati, 2014).

Dari berbagai konsep di atas, kajian ini mencoba memetakan respons dan permasalahan yang muncul di pesantren dalam menyikapi gagasan pendidikan kemaritiman. Tulisan kajian ini penting untuk mengembalikan semangat kemaritiman dalam lembaga pendidikan keagamaan seperti pesantren.

\section{METODOLOGI}

Penelitian dilakukan dengan metode penelitian kualitatif, dengan pendekatan studi kasus. Kasus yang dipilih adalah pesantren Bisnis.com Istana Mulia Cinangka Banten. Pertimbangan pemilihan pesantren ini didasarkan bahwa: 1) setelah menelusuri dari kota Banten Lama, ternyata sulit menemukan pesantren yang syarat dengan kultur maritim. Kebanyakan pesantren lebih mengutamakan tafaquh fiddin dalam pengertian pesantren untuk pemahaman kitab-kitab rujukan agama. Karena itu, jarang sekali ditemukan pesantren yang akrab dengan kultur kelautan; 2) Pesantren Bisnis.com Istana Mulia masuk dalam daftar pertama pesantren yang tercatat sebagai pesantren maritim/bahari di Kementerian Agama Kanwil Provinsi Banten; 3) Pesantren ini berlokasi di daerah pantai, tepatnya di sekitar pantai Anyer Cilegon Banten.

Pengumpulan data dilakukan dengan cara mengunjungi lokasi yang didahului penelusuran untuk membaca konstruksi pesantren di daerah pantai mulai dari Banten Lama hingga ke wilayah Serang Barat. Selain kunjungan, pengumpulan data dilakukan dengan wawancara dan pengamatan mendalam. Sumber informan untuk pengumpulan data ini melibatkan beberapa pihak yang terdiri pejabat Kementerian Agama di Kantor Wilayah Banten, Pengasuh Lembaga Pesantren sasaran penelitian, sebagian pengajar pada pesantren sasaran, dan sebagian santri pesantren sasaran. Selebihnya data pendukung diperoleh dengan cara membaca data kepustakaan serta data-data yang mungkin dihimpun dari beberapa sumber seperti internet dan media massa.

Data yang terkumpul kemudian dikonstruksi untuk menjawab pertanyaan dasar penelitian tentang pengembangan pendidikan keagamaan berbasis kemaritiman. Karena penelitian ini termasuk kajian yang awal mengenai pesantren maritim, maka analisa dan paparan hasil penelitian ini lebih banyak menggunakan teknik eksploratif.

\section{HASIL DAN PEMBAHASAN}

\section{Konteks Sejarah Banten : Poros Maritim Tempo Dulu}

Untuk menelusuri jejak pesantren dalam pengembangan budaya Maritim, peneliti tertarik untuk melacak jejak sejarah maritim dalam sejarah Banten. Sejarah menjadi alat untuk mereorientasi sistem kelautan Indonesia dan jalan untuk membangun kembali budaya maritim, sehingga unsur-unsur yang bermata pencaharian hidup dan masyarakat pendukung budaya maritim akan kembali menemukan kejayaannya (Pribadi, 2017).

Setelah Malaka Jatuh ke tangan Portugis pada tahun 1511, maka para pendakwah dan pejuang Malaka yang kebanyakan adalah muslim bertebaran seantero nusantara. Momentum ini menjadikan Islam berkembang masif di nusantara melalui jalur maritim. Berbagai pelabuhan dan kekuasaan Islam di nusantara banyak terletak di pantai-pantai seperti Demak, Cirebon, Banten (Pianto, 2017).

Menghadapi kolonialisme Barat, Banten pernah menjadi pusat mobilisasi persiapan penyerangan Portugis di Malaka yang dipimpin oleh Pangeran Sabrang Lor (Adipati Unus). Mobilisasi melibatkan kapal-kapal dari Gowa 
dan Pasukan dari Demak berkumpul di Banten. Walaupun serangan Adipati Unus ke Malaka ini yang dilakukan dua kali yaitu tahun 1513 dan 1518 belum membuahkan kemenangan, namun jejak Adipati Unus telah menjadi warisan spirit bagaimana orang nusantara dengan gagah, berani menantang setiap kehadiran penjajah di negeri ini. Makam Adipati Unus yang meninggal ketika memimpin penyerangan Malaka 1521 dan dimakamkan di Kota Banten Lama menjadi bukti penting bahwa Banten saat itu telah menjadi tempat penting dalam kepemimpinan lautan di nusantara.

Banten pernah terkenal sebagai sebuah kota pelabuhan yang sangat ramai dengan masyarakatnya yang terbuka dan makmur. Semula pada abad ke-5 Banten adalah bagian dari Kerajaan Tarumanagara. Kerajaan Banten berdiri 1525. Pendapat lain mengatakan bahwa Banten berdiri pada tahun 1520 (Kartodirjo, 1966). Pembangunan Banten sebagai kota perdagangan di mulai dengan pembangunan Istana Sorosowan, alun-alun dan masjid atas perintah Syarif Hidayatullah (Sunan Gunung Jati) kepada anaknya Maulana Hasanudin yang dikerjakan kurang lebih antara tahun 1522 dan selesai pada tahun 1526 . Oleh penguasa lokal, Arya Surajaya, pada tahun 1526 Banten diserahkan kepada Sunan Gunung Jati. Gunung Jati kemudian menobatkan anaknya Maulana Hasanudin untuk memimpin Banten (Graaf and Pigaud, 1989)

Kebesaran Banten sebagai kota Maritim mengalami masa jayanya semasa pemerintahan Sultan Ageng (1651-1683). Saat itu Banten mengalami masa keemasannya. Abad ke-17 Masehi, Banten merupakan salah satu pusat perniagaan penting dalam jalur perniagaan internasional di Asia. Lombard (2005) menyatakan salah satu kawasan laut nusantara yang dianggap sebagai media pertemuan kebudayaan antar kelompok masyarakat adalah Selat Sunda, semasa kekuasaan Kerajaan Banten (Lombard, 2005). Seorang pelaut dari Prancis, Claude de Forbin, dalam catatan perjalanan tahun 1686 yang dibukukan dalam Dorleans (2006) mengemukakan betapa besar dan kosmopolitannya Banten yang ia kunjungi pada tahun 1670 (Octavian and Yulianto, 2014).
Daerah kekuasaan Banten mencakup juga wilayah yang sekarang menjadi provinsi Lampung. Ketika orang Belanda tiba di Banten untuk pertama kalinya, orang Portugis telah lama masuk ke Banten. Kemudian orang Inggris mendirikan loji di Banten, baru kemudian disusul orang Belanda. Selain itu, orang-orang Perancis dan Denmark pun pernah datang di Banten. Sayangnya setelah Sultan Ageng turun tahta (1683) kebesaran Banten mengalami kemunduran dan kemudian Belanda mengambil alih.

Kebesaran Banten sebagai kota pelabuhan selanjutnya berpindah ke Sunda Kelapa (Jayakarta). Belanda pada tahun 1605 mulai berpikir untuk mencari pelabuhan baru yang bisa menggantikan posisi Banten (Untoro, 2006). Setelah Belanda berhasil merebut Jayakarta (1619), Pieter Both yang menjadi Gubernur Jenderal VOC pertama, lebih memilih Jayakarta sebagai basis administrasi dan perdagangan VOC daripada pelabuhan Banten, karena pada waktu itu di Banten telah banyak kantor pusat perdagangan orang-orang Eropa lain seperti Portugis, Spanyol kemudian juga Inggris, sedangkan Jayakarta masih merupakan pelabuhan kecil. Karena kemudian menjadikan Batavia sebagai pusat pendudukan di Nusantara, maka selanjutnya kebesaran Batavia menggantikan Banten.

Kebesaran Banten sebagai kota maritim antara 1522-1683 telah menjadikan kota ini selain titik temu arus perniagaan dari Makassar dan Mataram, Banten juga telah menjelma menjadi kota internasional yang melibatkan perwakilan negara-negara seperti Portugis, Spanyol dan Inggris mempunyai loji di daerah ini. Banten juga telah menjadi pusat perkembangan Islam melalui peran Syekh Yusuf dari Makassar. Ketika kerajaan Gowa ditaklukkan Belanda (1699), Syekh Yusuf pindah ke Banten semasa Sultan Ageng dan diangkat menjadi mufti di sana. Pada periode ini Kesultanan Banten menjadi pusat pendidikan agama Islam, dan Syekh Yusuf memiliki murid dari berbagai daerah, termasuk 400 orang asal Makassar yang dipimpin oleh Ali Karaeng Bisai. Ketika pasukan Sultan Ageng dikalahkan Belanda tahun 1682, Syekh Yusuf ditangkap dan diasingkan ke Srilanka pada bulan September 1684 (Kila, 2018). 
Pertanyaannya kemudian, setelah Banten pernah menjadi kota Maritim yang pernah berjaya sekian waktu di masa lalu, adakah semangat kemaritiman itu masih tersisa dalam kultur masyarakat Islam di Banten, khususnya pada kultur pendidikan di pesantren. Pertanyaan ini yang mendorong penulis ingin melihat kultur maritim yang mungkin terdapat di pesantren di daerah Banten.

Penelitian dimulai dengan usaha peneliti melacak lembaga pendidikan Islam tradisional yang ada di sekitar Banten lama. Namun ternyata pesantren lama yang ada di sekitar Banten lama adanya di Tanara, tempat Syekh Yusuf menetap setelah masuk menjadi mufti di Banten. Beliau menetap di daerah Tanara, kurang lebih $32 \mathrm{Km}$ dari Banten Lama. Tanara kemudian waktu itu menjadi pusat keilmuan Islam tradisional di Banten hingga sekarang.

Untuk melacak kembali sisa kultur kemaritiman dalam pendidikan tradisional pesantren di Banten, penulis mengawali dengan mengunjungi situs Banten Lama. Sayang sekali di sana tidak ada pesantren, yang ada hanya beberapa majelis taklim. Kebesaran Banten sebagai kota Maritim, hampir-hampir tidak menyisakan tradisi kuat yang masih mudah dijumpai di lembaga pendidikan pesantren. Pesantren seakan telah menjadi lembaga ilmu yang tercerabut dari akar kemaritiman yang telah menyebarkan Islam ke seluruh pelosok nusantara. Hal ini bisa juga dibaca, dengan datangnya kolonialisme, pesantren menjadi masuk ke daerah pedalaman dan menjadi basis perlawanan dari hutan. Perlawanan melalui kejayaan maritim, runtuh manakala kekuatan kolonialisme telah menguasai pantai-pantai di nusantara.

Sementara pesantren Tanara sejak awal lebih memfokuskan diri pada tafaquh fiddin. Itu berarti pesantren ini lebih menekankan diri pada pengembangan keilmuan agama. Ada kecenderungan umum bahwa pesantren hadir di lokasi-lokasi tertentu dan tidak jarang di daerah terpencil. Selanjutnya pesantren lebih mengutamakan proses pendidikan keagamaan. Sedangkan ketrampilan hidup (lifeskills) diajarkan sekedarnya dengan memanfaatkan potensi yang ada di sekitarnya. Baru belakangan ada pesantren yang berkembang menjadi holding, semacam induk dari berbagai unit kegiatan. Selain sebagai lembaga keilmuan, pesantren belakangan juga mempunyai lembaga usaha, bahkan layanan kesehatan untuk masyarakat.

Menghadapi gagasan menjadikan Indonesia sebagai poros maritim dunia, menyadarkan kita kembali bahwa kita adalah bangsa yang memiliki wilayah lautan yang sangat luas. Selama ini kita dininabobokan dengan penghasilan dari pertanian dan sumber daya alam di daratan. Kita miskin sekali memanfaatkan laut sebagai ruang lingkup kebudayaan kita. Dalam konteks ini, pertanyaan juga diajukan kepada lembaga sosial bernama pesantren. Bagaimana pula lembaga pendidikan pesantren menyambut gagasan kebudayaan maritim ini.

Untuk mencari pesantren di Banten yang mempunyai kedekatan dengan kultur maritim, peneliti merasa kesulitan. Dari lapangan, pesantren-pesantren yang ada lebih mendahulukan fungsi pesantren sebagai tempat mengajarkan ilmu dan kurang menggauli khazanah maritim. Di lokasi Banten lama ada pesantren tahfid yang tidak ada sangkut pautnya dengan ketrampilan hidup (lifeskills) kelautan. Sementara itu, kalau di pesantren di Tanara, pesantren yang digagas keturunan keluarga Syekh Yusuf memosisikan diri sebagai pesantren ilmu yang juga jauh dari kultur maritim.

Pilihan berikutnya untuk membidik pesantren yang mempunyai minat mengembangkan pesantren maritim jatuh pada daftar pertama yang diusulkan Kemenag Kanwil Banten. Pada daftar pertama, Kementerian Agama Kanwil Banten menunjuk pesantren Bisnis.com Istana mulia yang berlokasi di Kampung Nangkabeurit, Bantarwaru Cinangka Serang Banten dalam urutan pertama pesantren maritim di Banten. Pesantren ini dianggap terdepan dalam mengembangkan skills kemaritiman di pesantren daerah Banten.

Potensi Provinsi Banten dalam pengembangan budaya maritim sesungguhnya sangat besar. menurut statistik kelautan dan perikanan Banten (2014), Provinsi Banten memiliki 131 Desa Pesisir yang tersebar di 6 wilayah Kabupaten di Provinsi Banten, di antaranya Kab. Lebak (22 desa pesisir), Kab. 
Pandeglang (35 desa pesisir), Kab. Serang (36 desa pesisir), Kab. Tangerang (23 desa pesisir), Kota Cilegon (13 desa pesisir), Kota Serang (2 desa pesisir). Potensi perairan umum Provinsi Banten antara lain sungai (150 buah dengan total panjang sungai $2261,0 \mathrm{Km})$, cekdam/ waduk (17 buah dengan total luas $620,5 \mathrm{Ha}$ ), danau/situ (72 buah dengan total luas $226,6 \mathrm{Ha}$ ), rawa (34 buah dengan total luas 1442,9 Ha), dan genangan lainnya (58 buah dengan total luas 432,6 Ha). Sedangkan luas perairan laut Provinsi Banten sebesar 11.486,72 Km2 yang tersebar di wilayah Kabupaten dan Kota Provinsi Banten. Daerah yang memiliki luas perairan laut terbesar adalah Kabupaten Pandeglang, yaitu sebesar 1.702,00 Km2, sedangkan BPS Banten dalam Angkat (2017), Kabupaten Serang merupakan daerah yang memiliki luas areal budidaya perikanan menurut kabupaten/kota dan jenis budidaya di Provinsi Banten, dengan luasan total mencapai 5.894,57 ha. Provinsi Banten mempunyai dua Wilayah Pengelolaan Perikanan (WPP) yaitu di Perairan Samudera Hindia dan Perairan Laut Jawa (Darma, 2019).

Banten juga menjadi jalur Alur Laut Kepulauan Indonesia (ALKI) berdasarkan The United Nations Convention on the Law of the Sea (UNCLOS) 1982. Alur ini merupakan alur untuk pelayaran dan penerbangan yang dapat dimanfaatkan oleh kapal atau pesawat udara asing di atas laut tersebut untuk dilaksanakan pelayaran dan penerbangan damai dengan cara normal. Selat Sunda sebagai salah satu selat tersibuk di Indonesia merupakan bagian dari Alur Laut Kepulauan Indonesia (ALKI) I, yang menghubungkan perairan Samudera Hindia melewati Selat Karimata menuju Laut Natuna Utara atau sebaliknya. Pengamanan sebagai implikasi daerah ALKI-I di Selat Sunda, membutuhkan ketahanan maritim masyarakat wilayah Banten (Eko Yuri, Gunawan and Barnas, 2018).

\section{Respons dan Transformasi Pesantren terhadap Gagasan Pesantren Maritim}

Gagasan Indonesia sebagai poros maritim, menurut Tasrifin Tahara (2016) merupakan usaha reorientasi pembangunan bangsa dari land-centered ke marine centered develompment. Dalam pemahaman ini, poros maritim berisi visi misi dan langkah strategis untuk menciptakan kedaulatan (ideologi, politik, sosial, ekonomi, termasuk pangan dan energi dan hankam) dengan menjadikan laut sebagai pusat orientasi ideologis (wawasan dan mentalis) dan sumber material pembangunan. Dalam konteks ini, poros maritim lebih berorientasi pada pengoptimalan pengelolaan sumber daya laut -kombinasi antara penguasaan, pemanfaatan, pemeliharaan, konservasi, dan restorasi-jika dibutuhkanuntuk kepentingan kita sendiri (Tahara, 2016b).

Setelah menyusuri lembaga pesantren mana yang paling pas untuk rintisan pesantren maritim, dan penulis tidak menemukan lembaga pesantren yang syarat dengan budaya maritim. Kultur maritim di Banten, termasuk di pesantren, nampaknya sudah jauh dari watak dan karakter mereka. Degradasi perniagaan maritim Banten tak pelak dilatarbelakangi oleh masuknya kekuasaan Belanda di wilayah ini yang tidak hanya bertujuan untuk melakukan upaya perdagangan, tetapi juga berhasrat menjalankan praktik monopoli perdagangan di pelabuhan. Proses ini berjalan beriringan dengan degradasi kebudayaan maritim masyarakat nusantara lainnya (Supriyono, 2013; Octavian and Yulianto, 2014).

Sejarah pendidikan Islam di Banten, termasuk di pesantren, pun kemudian disibukkan dengan pengajaran spiritual dan kejuangan untuk melawan penjajah. Muslimah menyebutkan tokoh agama (ulama) kemudian lebih banyak menjadi pengarah kehidupan pribadi dan masyarakat dalam beragama, memberantas kebodohan melalui pendidikan, juga sebagai penggelora semangat jihad masyarakat untuk melawan penjajah (Muslimah, 2017).

Karena penulis kesusahan mencari pesantren berkarakter maritim, akhirnya penulis kembali ke petunjuk yang diberikan oleh Kemenag Kanwil Provinsi Banten. Dari Kemenag Kanwil Banten, penulis mendapatkan daftar pesantren Maritim di Banten sebanyak 6 buah, dan nomor satu disebutkan pesantren Bisnis.com Istana Mulia yang berlokasi di dekat Pantai Anyer, dan masuk wilayah Serang. Segeralah penulis meluncur ke sana untuk mengkaji sejauh mana pengembangan budaya Maritim sudah diimplementasikan di pesantren tersebut. Penulis sebelumnya membayangkan bahwa pesantren ini karena dekat pantai, maka 
ada aktivitas pesantren yang berhubungan dengan laut.

Namun bayangan itu ternyata jauh dari kenyataan. Dari sisi lokasi, adalah benar bahwa pesantren ini berlokasi tidak jauh dari laut, sekitar 1 kilometer dari bibir pantai. Berbeda dari bayangan sebelumnya, ternyata pesantren ini lebih dekat dengan suasana pesantren bercorak perkebunan. Pesantren ini lebih mengembangkan pesantren sebagai tempat wisata spiritual berbasis kebun. Tidak ada sedikitpun aktivitas yang berbau kelautan. Padahal sebenarnya pesantren ini potensial untuk mengembangkan pesantren model kelautan karena dari sisi geografis berdekatan dengan laut. Belum adanya konsep mengenai pesantren maritim menjadi sebab pesantren ini belum mengembangkan budaya maritim. Hal ini sesuai dengan pengakuan pimpinan pesantren Bisnis.com Istana Mulia.

Kami memang belum memahami konsep pesantren maritim. Kami menunggu pedoman yang mestinya kami terima dari Kementerian Agama. Ketika ada wacana pesantren Maritim, memang kami mengajukan diri untuk menjadi salah satu pesantren untuk dikembangkan dalam perspektif pesantren maritim ini. Namun sejauh ini kami belum mendapatkan pedoman apapun untuk melaksanakan pesantren maritim (Wawancara dengan Ayi Muzayini, Pengasuh Pesantren Bisnis.com).

Nama lengkap pesantren ini adalah pesantren Bisnis.com Istana Mulia. Berlokasi di Kampung Nangkabeurit, Bantarwaru Cinangka Serang Banten. Terletak di pantai Barat Pulau Jawa, dari arah Cilegon pesantren ini berada kurang lebih $17 \mathrm{Km}$ sebelum sampai Pantai Carita Anyer Banten. Berjarak kurang lebih 1 $\mathrm{Km}$ dari laut, pesantren ini potensial untuk digagas sebagai pesantren maritim. Pesantren ini berdiri pada tahun 2012 oleh seorang anak muda bernama ustaz Ayi Muzayini yang saat penulis datang menemuinya pertama kali berusia kurang lebih 40 tahun.

Selintas tentang Ustaz Ayi Muzayini, dia adalah seorang anak petani udik dari daerah Sukabumi. Ayi lahir September 1976 di sebuah kampung Mariuk, Jampang Tengah Kabupaten Sukabumi, tepatnya sekitar 78 kilometer dari pusat kota Pelabuhan Ratu. Dilahirkan dari keluarga sederhana, Ayi tidak bisa menikmati masa belajar yang memadai di kampungnya. Pada tahun 1986 ia harus mengalami putus sekolah karena kurang biaya. Ayahnya yang tidak sanggup membiayai pendidikan Ayi, akhirnya menyarankan kalau hidup Ayi mau berubah, maka pergilah ke Jakarta. Itupun untuk pergi ke sana, Ayi kecil harus mengumpulkan uang saku sendiri. Maka Ayi kecil pun mengumpulkan uang saku itu dengan menjadi kuli pengangkut singkong.

Setelah sedikit uang terkumpul, Ayi kecil yang waktu itu berumur 10 tahun, untuk memperbaiki nasib memberanikan diri pergi meninggalkan kampung halaman. Ia berjalan kaki meninggalkan kampungnya sepanjang kurang lebih $25 \mathrm{Km}$ menuju jalan besar untuk menuju Jakarta. Hal itu dilakukan untuk menghemat uang sakunya. Sampai di kota Metropolitan, Ayi bekerja menjadi kernet jahit. Gaji tiga puluh lima ribu rupiah seminggu hanya cukup untuk makan sehari-hari. Setiap malam, ia tidur beralaskan bahan levis dan terkadang tidur di atas mesin obras. Ruangannya sangat sempit, bau apek, panas dan pengap, bahkan kadang tidur ditemani kecoa, tikus got dan curut nying - nying. Namun apalah daya, keadaan memaksanya untuk tetap bertahan.

Tiga bulan di Jakarta, karena usianya masih terlalu kecil untuk bekerja, kemudian ada yang menyarankan agar Ayi tinggal di Panti Asuhan. Menerima tawaran itu, Ayi kecil bergabung ke Panti Asuhan yang berafiliasi dengan Pondok Pesantren Darunnajah Jakarta. Selama enam tahun Ayi Muzayini menempuh pendidikan di sana. Dari sana dia mendapatkan ijazah pendidikan jenjang menengah pertama dan menengah atas. Tidak sia-sia Ayi Muzayini merantau ke Jakarta, karena dia tidak jadi ketinggalan dalam pendidikan formalnya.

Berbekal dengan ilmu agama dan ijazah pendidikan menengah atas, Ayi Muzayini suatu saat berkesempatan itu melanjutkan hidupnya untuk merantau ke luar negeri. Secara kebetulan ada yang menawarinya pergi ke Kuwait. Maka demi pengalaman yang lebih luas, sebagaimana tekatnya dia meninggalkan kampung halaman di Sukabumi, kali ini dia membuat keputusan besar dengan meninggalkan Indonesia mencari 
pengalaman hidup di negeri Timur Tengah, Kuwait. Di Kuwait dia belajar pendidikan di Islamic Boarding School state of Kuwait (19931995) dan melanjutkan studi agamanya ke Religious Institute of Kuwait (1995-1998).

Tahun 1998, Ayi Muzayini pulang kembali ke Jakarta. Untuk menyelesaikan pendidikan formalnya yang sempat ia tinggalkan, ia mendaftar pendidikan di S1 jurusan Hubungan Internasional Universitas Budi Luhur Jakarta. Pengalamannya selama di Kuwait ditambah dengan pilihan program studi di bidang hubungan internasional serta hobi di bidang IT menambah wawasannya di bidang jaringan komunikasi global. Skills dan wawasannya menyebabkan dia mempunyai kecakapan yang spesial yang memungkinkan ia dipercaya menjadi konsultan di bidang IT di berbagai perusahaan (Muzayini, 2010).

Setelah eksis sebagai profesional di bidang informasi teknologi, pada tahun 2011 Ayi Muzayini merasa terpanggil untuk mendirikan lembaga pendidikan pesantren. Pesantren yang digagas mempunyai ciri, yaitu Pertama, Pesantren yang fokus mengembangkan lifeskills anak didik berbasis online. Semua santri selain mengaji untuk membentuk mental, sejak dini sudah dikenalkan berselancar melalui internet. Peserta didik diperbolehkan, bahkan diharuskan mempunyai laptop. Kedua, Pesantren sebagai tempat wisata spiritual. Gagasan ini diwujudkan dengan menjadikan lokasi pesantren sedemikian rupa sebagai pesantren yang memberikan pencerahan bagi generasi muda. Bangunan pesantren dibuat seperti lokasi outbond. Bangunan-bangunan dinamai kota-kota besar dunia seperti Jayakarta, Madinah, Tokyo, Istanbul. Ketiga, Dengan adanya wacana pengembangan pesantren maritim, pesantren ini mengajukan diri untuk menjadi rintisan pesantren maritim. Selain pesantren berbasis online dan pesantren sebagai objek wisata spiritual, maka dengan pengembangan gagasan pesantren maritim, maka gagasan itu menjadi muatan ketiga dari keberadaan pesantren ini

Kronologi perkembangan pesantren ini yang bermula dari diskusi online ustaz Ayi dengan para warganetnya. Diskusi ini berkembang hingga menjadi keinginan untuk melakukan aksi nyata membentuk lembaga pendidikan pesantren. Perkembangan pesantren hingga merespons gagasan pesantren maritim dapat disebutkan: periode diskusi online (20062011), periode aksi nyata pendidikan pesantren/periode offline (2011-2016), menggagas pesantren maritim (2016).

Tabel. 1. Asal negara dan pengunjung website PesantrenBisnis.com

\begin{tabular}{lr}
\hline \multicolumn{1}{c}{ Asal negara } & \multicolumn{1}{c}{ Jumlah } \\
\hline Indonesia & 277.906 \\
Amerika Serikat & 50.891 \\
Rusia & 22.599 \\
Ukraina & 15.953 \\
India & 13.238 \\
Israel & 8.657 \\
China & 8.086 \\
Jerman & 5.221 \\
Inggris & 4.650 \\
Perancis & 4.013 \\
\hline
\end{tabular}

Periode diskusi online (2006-2011). Periode ini dirintis sebelumnya dimulai dari sebuah pengelolaan website Bisnis.com. secara kebetulan penggagas pesantren ini, ustaz Ayi Muzayini, mempunyai keahlian di bidang teknologi informasi atau IT, maka rencana pesantren ini muncul sebagai tindak lanjut dari pengelolaan website Bisnis.com ini. Di tengah profesinya sebagai kreator dan konsultan dibidang IT di berbagai perusahaan di Jakarta, Ustaz Ayi Muzayini memiliki pemikiran untuk membentuk sebuah portal untuk memajukan anak-anak bangsa di bidang IT. Karena itu dia mencoba menularkan dan mewujudkan imiannya itu dengan membuat website bernama Bisnis.com. dari website ini Ustaz Ayi 
Muzayini mencoba membagi berbagai pemikiran terkait dengan pengembangan kesadaran IT bagi generasi muda.

Bermula dari diskusi yang terjadi antara pengelola website Bisnis.com dengan warganet, maka mulai muncul pemikiran perlu pembangunan kesadaran IT diwujudkan dalam lembaga pendidikan. Menurut Ustaz Ayi Muzayini, gagasan mendirikan pesantren Bisnis.com bermula dari diskusi dalam media sosial antara Ustaz Ayi dengan pengikutnya. PesantrenBisnis.com secara online didirikan pada tahun 2009 dengan pengunjung dari berbagai negara maju di dunia. Jumlah pengunjung sampai dengan 09 Oktober 2015 sebanyak 528.076, dengan pengunjung terbanyak asal Indonesia 277.906 dan Israel mendapat urutan ke-6 dengan jumlah pengunjung 8.657 (Tabel 1).

Kesadaran perlu lembaga pendidikan yang mengajarkan anak-anak melek IT sedini mungkin semakin mendapatkan momentumnya ketika Ustaz Muzayini mempunyai anak usia SMP yang butuh lembaga pendidikan yang mengembangkan bakatnya sejak dini. Dari kesadaran ini, Ustaz Muzayini bertekad untuk mendirikan lembaga pendidikan yang memenuhi harapan itu. Sebagai orang yang pernah dibesarkan di panti asuhan, Ustaz Muzayini tergerak untuk memulai di bidang pendidikan ini dengan membina anak yatim.

Periode offline (2011-2016). Pesantren ini kemudian direalisasikan secara faktual diawali dengan inisiatif pendiri Istana Yatim Indonesia yang melakukan kerja sama dengan Yayasan Darul Anwar Banten, pada tahun 2011. Hal tersebut bertujuan untuk membantu dan memfasilitasi siswa Darul Anwar yang yatim dan duafa agar dapat bersekolah. Kesepakatan tersebut langsung dikomandani oleh Pendiri dan CEO Istana Mulia Groups (IMG) Ustaz Ayi Muzayini, dan Yayasan Darul Anwar Banten diwakili oleh Ketua Yayasan Darul Anwar Banten yang merangkap Kepala Sekolah Darul Anwar Ustaz Dedi Suhandi.

Perkembangan berikutnya, IMG merasa perlu mengembangkan diri menjadi pesantren yang mandiri. Niat ini dimulai dengan pembelian tanah pertama seluas $2.750 \mathrm{~m}^{2}$ dan membangun 2 kelas dan 2 kantor serta 1 masjid. Dalam rangka ikut mewujudkan Pendidikan berstandar internasional yang Unggul dan Terpercaya dalam dan luar negeri, maka IMG mulai mengembangkan dan membangun Komplek Taman Wisata Pendidikan (TWP) secara serius, yang dimulai 9 Maret 2012 di atas tanah seluas $4.000 \mathrm{~m}^{2}$.

Landscape pesantren ini dibangun lebih menyerupai dengan lokasi dengan gaya cottagecottage. Seperti gaya villa di Bogor, namun dengan konteks kebun. Lokasi pesantren dibuat menyerupai tempat outbond. Dari pengakuan penggagasnya, Ustaz Ayi Muzayini, salah satu konsep pengembangan pesantren ini adalah pesantren sebagai tujuan wisata. Selain konsep cottage-cottage, pesantren ini juga dilengkapi bendera-bendara dari berbagai bangsa. Pesantren ini menampung santri dari berbagai negara. Demikian juga nama-nama masingmasing pondokan diberi nama-nama kota-kota terkenal di dunia seperti Istanbul, Tokyo, Jayakarta, Madinah. Pemberian nama kota terkenal di dunia ini lebih dimaksudkan untuk membuat anak didik sedini mungkin mengenal kota-kota besar dunia.

Selanjutnya PesantrenBisnis.Com (Entrepreneur Academy) merintis SMP Informasi Teknologi Istana Mulia. Rekrutmen siswa dilakukan melalui media online dan berhasil menjaring siswa dari berbagai daerah. Angkatan pertama, sekolah ini berhasil merekrut 18 siswa dari beberapa provinsi di Indonesia, yaitu Banten, Jawa Barat, Jakarta, Bengkulu, dan Manado.

Melihat perkembangan yang begitu cepat dan kebutuhan sarana prasarana yang lebih banyak, maka IMG terus berupaya mengoptimalkan daya upaya dalam pemenuhannya, sehingga pada tahun 2015 , pendiri dan CEO IMG dan Tim harus mengalihkan berbagai aset dan kekuatan finansial dari berbagai sumber untuk pengembangan TWP SMP Informasi Teknologi Istana Mulia Anyer Carita. Pada bulan Oktober 2015 total tanah yang telah dibebaskan IMG seluas $34.000 \mathrm{~m}^{2}$ (3,4 ha) dengan total luas bangunan, jalan dan taman seluas $10.300 \mathrm{~m}^{2}$ (1,3 ha).

Atas upaya tim cyber dan google marketing santri, setiap tahun santri terus bertambah dengan sangat cepat, pada tahun 2014 Jumlah santri angkatan ke-2 berjumlah 78 orang dan pada tahun ajaran 2015-2016 
angkatan ketiga yang lulus tes dan diterima di Istana Mulia berjumlah 115 orang dari jumlah yang mendaftar online 423 orang. Asal sekolah santri ini berasal dari berbagai wilayah Indonesia. Walau Provinsi Banten, Jawa Barat, dan DKI Jakarta masih menjadi mayoritas asal santri, namun santri ada juga yang berasal dari Papua, Palembang, Lampung, Gorontalo, Banjarmasin, Kalimantan, Bengkulu, Padang, Medan, Manado, dan lainnya. Total santri yang lulus tes dan diterima di Istana Mulia pada bulan Oktober 2015 adalah sebanyak 192 santri.

Periode merintis pesantren maritim (2016). Untuk pengembangan pesantren ke depan, menurut pimpinan pesantren ini, mereka berminat untuk menjadi salah satu pesantren yang mengembangkan pesantren maritim atau pesantren bahari. Maka ketika Kementerian Agama merintis pengembangan pesantren maritim yang dicanangkan dengan keterlibatan Kementerian Agama melalui Sail Tomini 2015 di Sulawesi Tengah, Pesantren Bisnis.com Istana Mulia Cinangka Serang mengajukan diri menjadi salah satu pesantren yang siap dikembangkan menjadi pesantren maritim.

Di Provinsi Banten terdapat enam pesantren yang mengajukan diri menjadi pesantren bahari atau pesantren maritim, yaitu 1) Pesantren Bisnis.com Istana Mulia Nangkabeurit Bantar Waru Cinangka Serang; 2) Pesantren Nurul Mursyidah Pegadungan Karangtanjung, Pandeglang; 3) Pesantren Manahijussadat Serdang Pasir Keong, Cibadak Lebak; 4) Pesantren Nurul Fikri Babakan Padang Cibungur, Leuwidamar, Lebak; 5) Pesantren As-Syifa Cikadu Indah Tanjungjaya Panimbang Pandeglang; 6) Pesantren Nurul Hikmah Cipacung Karangsuraga Cinangka Serang (Data Kemenag Kanwil Banten, 2019).

Menuju pengembangan pesantren maritim, Pesantren Bisnis.com Istana Mulia belum mempunya konsep khusus untuk menuju ke sana. Ketika peneliti datang ke lokasi, mereka baru mengumpulkan informasi bagaimana mengembangkan pesantren maritim tersebut. Menurut pengamatan peneliti, pesantren bisnis.com Istana Mulia mempunyai beberapa potensi yang bisa dikembangkan dalam kerangka pesantren maritim, sebagai berikut.
Pertama, Pesantren Bisnis.com Istana Mulia sejauh ini membangun keunggulan skills di bidang IT online. Dengan keunggulan tersebut, pesantren ini bisa mempromosikan hasil laut dan olah lanjut hasil laut yang dihasilkan oleh masyarakat sekitar melalui media online. Hal ini akan mempercepat produk kelautan yang dimediasi pesantren dikenal oleh pasar. Kedua, Kedekatan lokasi Pesantren dengan laut memungkinkan pesantren dapat berinisiatif melakukan usaha eksplorasi dan budi daya komoditi kelautan seperti budidaya ikan dan pengembangan rumput laut. Ketiga, Dengan nama pesantren Bisnis.com memungkinkan pesantren ini melakukan usaha lanjut dari komoditi kelautan seperti reproduksi hasil laut seperti pengalengan ikan, pembuatan minuman berbahan baku rumput laut. Keempat, Kedekatan lokasi pesantren dan minat pesantren yang ingin mengembangkan pesantren sebagai tujuan wisata spiritual memungkinkan pesantren ini mengembangkan wisata spiritual bernuansa kelautan.

Menyikapi tentang wacana pesantren maritim, Ustaz Ayi Muzayini menjelaskan bahwa pesantren Bisnis.com Istana Mulia sangat menunggu konsep pesantren maritim ini. Diakui oleh mereka, bahwa mereka masih merasa kebingungan mulai dari mana untuk mengembangkan pesantren maritim ini. Karenanya mereka sangat menanti konsep pesantren maritim ini, karena kami memang mempunyai konteks sosial dan geografis yang dekat dengan kelautan.

Barangkali yang bisa kami lakukan adalah memulai dengan memetakan potensi kelautan yang ada pesantren kami, seperti hasil tangkap ikan para nelayan, produksi makanan dari hasil laut seperti kerupuk udang, terasi. Kami dengan pesantren yang kuat di bidang online, akan mempromosikan produkproduk kelautan yang dihasilkan nelayan di sekitar kami (Wawancara Ayi Muzayini, Pengasuh Pesantren Bisnis.com).

\section{Pesantren Maritim: Konsep dan Implementasi Program}

Herlan Prasetyo (2016) menyebutkan
bahwa pembangunan maritim perlu


diimplementasikan ke dalam empat bidang pembangunan nasional secara berkesinambungan. Keempat bidang itu meliputi Bidang politik, ada kebijakan pembentukan Kementerian Koordinator Kemaritiman dan Sumber daya dan pembentukan Satuan Tugas Pemberantasan Illegal Fishing. Bidang ekonomi, ada kebijakan Tol Laut, dengan pengembangan kapal-kapal nelayan, pembangunan dan pengembangan pelabuhan, pembangunan Pusat Logistik Berikat (PLB), pengembangan industri galangan kapal. Kemudian ada kebijakan investasi asing industri perikanan dan kebijakan percepatan waktu bongkar muat (dwelling time) di pelabuhan, dengan memperbanyak jalur hijau barang, meningkatkan biaya denda, kereta api pelabuhan, meningkatkan sistem teknologi informasi, penambahan kapasitas crane (alat derek), dan penyederhanaan peraturan perizinan, serta pemberantasan mafia di pelabuhan. Bidang sosial budaya ada kebijakan pengembangan pariwisata bahari dan pengembangan pendidikan maritim. Bidang pertahanan dan keamanan (hankam) ada kebijakan pembentukan Badan Keamanan Laut (Bakamla), pengembangan alutsista TNI Angkatan Laut, dan pengembangan alutsista TNI Angkatan Udara (Prasetyo, 2016).

Pengembangan pesantren maritim merupakan bagian usaha perubahan pandangan masyarakat melalui bidang sosial budaya. Kalau mencermati perkembangan gagasan pesantren maritim di Indonesia dimulai dari pesantren Bisnis.com Istana Mulia Cinangka Serang, maka peneliti bisa mengatakan bahwa permasalahan pertama yang tampak nyata di lapangan adalah masalah kekosongan konsep tentang pesantren maritim. Ketiadaan konsep menjadi persoalan pertama yang dihadapi oleh Kementerian Agama ketika menggagas pesantren maritim. Hal ini yang menjadi temuan kami di lapangan, ditanyakan bagaimana gagasan tentang pesantren maritim, para pengelola tampak masih gamang dan belum bisa menyebutkan gagasan mereka sebenarnya tentang pesantren maritim. Mereka mengakui belum mempunyai pedoman atau konsep yang akan mereka kembangkan. Selama ini mereka menunggu panduan yang diberikan Kementerian Agama dalam menggagas pesantren maritim ini.
Kejadian serupa juga peneliti temukan ketika ketemu dengan beberapa pesantren di Sulawesi Selatan ketika peneliti mengikuti workshop pengembangan pesantren maritim yang dilakukan Puslitbang Pendidikan Agama dan Keagamaan di Kabupaten Bantaeng Sulawesi Selatan. Kebanyakan peserta yang berdomisili di pinggir lautan juga belum banyak memahami konsep Pesantren Maritim (Tahara, 2016a). Fakta ini sekaligus menunjukkan bahwa dari 360 pesantren yang mengajukan diri menjadi pesantren maritim dapat diduga juga belum mempunyai konsep yang jelas mengembangkan pesantren maritim.

Dari beberapa perbincangan yang penulis ikuti dalam menggagas pesantren maritim ini, ada beberapa permasalahan umum yang dihadapi pesantren yang bisa dirumuskan terkait pengembangan budaya maritim di pesantren. Beberapa permasalahan umum itu dapat disebutkan antara lain: 1) kalangan pengelola pesantren belum mengenali potensi laut yang ada di sekitar mereka; 2) Pengelola pesantren juga belum tahu caranya bagaimana memanfaatkan potensi laut; 3) Pengelola pesantren belum tahu bagaimana menjual hasil produk pengolahan potensi kelautan.

Pesantren mana yang sebaiknya menjadi sasaran pengembangan pesantren maritim? Pesantren-pesantren yang berlokasi di sekitar pantai tentunya menjadi sasaran utama pembangunan dalam rangka pengembangan pesantren maritim. Dengan tekstur negara kepulauan, di Indonesia banyak sekali mempunyai pesantren yang berada di bibir pantai. Sayangnya pesantren yang banyak itu, kebanyakan atau hampir semuanya belum mempunyai konsep tertentu tentang pesantren maritim. Pesantren lebih banyak dipahami sebagai tempat tafaquh fiddin saja sehingga agak terabaikan pesantren sebagai tempat pemberdayaan sosial atau pesantren sebagai pembinaan lifeskills santri. Padahal kalau kita melihat ciri khas utama pesantren adalah kemandirian, kemandirian tidak hanya dalam hal lembaga tetapi juga sosok santri yang mandiri, ciri khas pesantren ini hendaknya mewarnai kemandirian para santrinya dalam menata kehidupan ekonomi.

Prasyarat pesantren maritim hendaknya di lokasi sekitar pantai banyak dimiliki 
pesantren di Indonesia. Dengan bentangan garis pantai yang panjang, dapat dipastikan bahwa Indonesia mempunyai ribuan pesantren di daerah pantai. Hanya saja keberadaan pesantren di garis pantai tidak bisa menjamin bahwa pesantren itu sudah masuk dalam kategori pesantren maritim. Kasus Pesantren Bisnis.com istana mulia yang dekat laut dan sangat berpotensi menjadi pesantren maritim ternyata belum memahami konsep atau arah pesantren maritim. Hal ini tampak dari ungkapan pimpinan pesantren yang menyatakan belum tahu hendak mau dibawa ke mana dengan gagasan pesantren maritim.

Namun dari daya dukung lingkungan, peneliti beranggapan bahwa pesantren Bisnis.com IMG memenuhi untuk menjadi rintisan pesantren maritim, karena didukung dengan fakta-fakta sebagai berikut: 1) lokasi pesantren Mulia ini dengan garis pantai berada kurang lebih $1 \mathrm{Km}$; 2) masyarakat di sekitar pesantren banyak yang mempunyai profesi yang berhubungan dengan laut seperti nelayan, pengkonsumsi ikan laut; 3) pesantren dapat mengembangkan program-program yang berkaitan dengan kelautan seperti turut serta dalam ekspose dan pemasaran produk kelautan.

Program pemerintah di bidang pengembangan kemaritiman dan peluang partisipasi pesantren. Pemerintahan di bawah kepemimpinan Presiden Joko Widodo telah pernah mengampanyekan Indonesia sebagai poros maritim dunia menjadi momentum yang tepat untuk memulai pesantren maritim ini. Wacana Indonesia sebagai poros maritim disampaikan pertama kali oleh Jokowi di musim kampanye presiden tahun 2014. Setelah menjadi Presiden, Jokowi mengulangi gagasan itu dalam KTT APEC di Beijing dan KTT G20 di Sydney. Saat itu Presiden Joko Widodo menyatakan perlunya investasi besar-besaran untuk mendukung program "Poros Maritim Dunia."

Menindaklanjuti gagasan itu, pemerintah Indonesia telah mengeluarkan Undang-undang yang menjadi dasar pengembangan eksplorasi laut melalui UU No. 32 Tahun 2014. UU tersebut menjadi dasar penegasan perubahan paradigma pembangunan yang berbasis kelautan (ocean based development). Hal ini menuntut perubahan perilaku dari masyarakat Indonesia yang sebelumnya didominasi budaya agraris, menuju masyarakat yang sadar dengan budaya kelautan.

Dalam menuju perubahan paradigma pembangunan, Kementerian Kelautan telah mencanangkan beberapa program prioritas di bidang kelautan antara lain 1) penanggulangan dan penyelesaian UU fishing dan keamanan laut; 2) Industri perikanan dan hasil laut; 3) tata ruang laut, konservasi dan rehabilitasi pesisir dan laut, serta wisata bahari; 4) kesejahteraan nelayan, pembudidayaan ikan dan petambak garam; 5) perundingan dan penetapan batas laut, penamaan laut dan pengelolaan pulaupulau kecil.

Dari beberapa program prioritas Kementerian Kelautan ini, pesantren bisa ambil bagian dalam program-program yang bisa dilakukan pesantren seperti ikut dalam pengembangan industri hasil laut, pembudidayaan ikan, dan industri garam pengembangan wisata bahari. Pesantren Bisnis.com Istana Mulia sendiri lebih pengembangan pemasaran industri hasil laut bekerja sama dengan masyarakat sekitar, budi daya perikanan dan pengembangan wisata spiritual bernuansa kelautan.

\section{Agenda Pengembangan Pesantren Maritim}

Secara umum menurut Prasetyo, tantangan yang akan dihadapi dalam mengubah cara pandang masyarakat, termasuk pesantren, adalah tantangan implementasi konsep poros maritim terkait sistem teknologi dan informasi, sarana dan prasarana, sumber daya manusia, dan kondisi dunia maritim Indonesia. Untuk menjawab berbagai tantangan itu diperlukan pelaksanaan program yang komprehensif didukung penelitian dan pengembangan secara berkelanjutan (Prasetyo, 2016). Perspektif ini bisa dipakai untuk membaca potensi pesantren dalam konteks pengembangan pendidikan berbasis maritim.

Dari hasil kajian dan refleksi di lapangan, untuk mengubah kultur masyarakat pesantren menjadi masyarakat yang sadar terhadap nilai lebih budaya maritim, dan akan membawa perubahan besar, diperlukan minimal satu dari tiga prasyarat: pertama, ada pesantren yang berlatar belakang kelompok sosial yang secara tradisional sudah menggantungkan hidupnya 
dengan laut. Kedua, intervensi pendidikan kemaritiman di pesantren, ketiga, adanya niatan komodifikasi potensi kelautan yang berbasis pada lembaga pesantren.

Tentang prasyarat pertama, PesantrenBisnis.com yang berada di Provinsi Banten mempunyai sejarah keberhasilan sebagai daerah kosmopolitan maritim pada zaman dahulu. Namun karena penjajahan, kultur sosial kemaritiman yang dimiliki masyarakat Banten memudar. Konteks sosial yang berdekatan dengan dunia maritim menjadi penting untuk menjadi basis pengembangan pesantren maritim. Dalam konteks ini, sangatlah urgen untuk melakukan penggalian nilai-nilai luhur masyarakat pantai yang menonjol dalam berbagai arena sosial, ekonomi dan politik (Tahara, 2018).

Untuk di daerah-daerah di luar Banten, sesungguhnya kelompok sosial yang secara tradisional di Indonesia yang sudah menggantungkan hidupnya dengan laut, banyak ditemukan kelompok sosial seperti ini. Misalnya suku Bajo di perairan Sulawesi dan suku Anak Laut di Kepulauan Riau. Mereka ini sudah akrab dengan laut. Mereka sudah terbiasa dengan ombak di laut. Kelompok tradisional seperti ini menjadi modal yang sangat potensial untuk menghasilkan putra-putra daerah mampu memaksimalkan potensi kelautan. Di masyarakat tradisional nelayan seperti itu, seyogyanya dijadikan sasaran pengembangan pesantren maritim ini.

Di Indonesia ada beberapa kelompok tradisional yang kehidupannya berbasis laut. Adrian Hooridge (1986) menyebutkan beberapa suku di Indonesia yang kehidupannya berorientasi laut seperti Suku Bajo, Bugis (Teluk Bone), Makassar (Galesong, Tallo, Pangkep), Mandar (Sulawesi Barat), Buton (Sulawesi Tenggara), Madura (Jawa). Mereka dianggap sebagai pewaris kebudayaan maritim di Asia tenggara sejak ribuan tahun silam. Kemudian muncul kelompok etnis yang lain yang juga berorientasi laut seperti penduduk Bawean, Masalembo, Sapudi, BonerateSelayar, Polu'e (Laut Flores), pemburu Paus di Lamakera. Suku-suku laut ini kehidupannya sudah akrab dengan laut, dan laut sudah menjadi sahabat mereka (Horridge, 1986).
Endang Susilowati menyebutkan etnis maritim di Indonesia meliputi suku Bajau/Bajo yang mendiami berbagai titik perairan seperti di sebelah timur Selat Makassar, pantai timur Kalimantan, Pulau Alor dan sekitarnya, Kepulauan Banggai, Kepulauan Togian di Teluk Tomini, Kepulauan Bacan, Kepulauan Sulu, dan lain-lain; suku Orang Laut di Selat Malaka dan perairan Sumatra Timur, sekitar Pulau Belitung (dikenal juga dengan sebutan Orang Ameng Sewang) dan Orang Laut di sekitar Pulau Bangka yang dikenal dengan sebutan Orang Sekak. Orang Laut yang berlabuh dan mendiami pesisir pantai Kalimantan Selatan selanjutnya dikenal sebagai Orang Banjar; yang mendiami pesisir pantai Sulawesi Selatan dikenal sebagai Orang Bugis; yang mendiami Pulau Irian dikenal sebagai Orang Tabati; dan yang mendiami Pulau Sumbawa, terutama di sekitar Nusa Tenggara Barat, dikenal sebagai Orang Mbojo. Selain itu masih ada Suku Mandar, Makassar, Buton, Sangir, Talaud, dan Madura (Susilowati, 2017).

Mereka menjadi sasaran strategis, termasuk pesantren yang ada di dalamnya, untuk menggarap kembali pengembangan modal budaya maritim yang sudah ada. Dengan beberapa sentuhan pembinaan dan pengembangan, pendidikan di lingkungan mereka akan sangat membantu untuk penguatan standar skills mereka. Mereka akan lebih mempunyai nilai lebih bila diberdayakan. Keahlian mereka nantinya bisa digunakan oleh negara seperti bekerja di angkatan laut dan laboratorium kelautan.

Kultur maritim kelompok-kelompok sosial tradisional seperti itu akan menjadi modal sosial dan budaya yang kuat bagi pesantrenpesantren yang tumbuh di tengah-tengah mereka. Pesantren yang syarat dengan pendidikan kemandirian, lifeskills hendaknya dapat mengambil best praktis ketrampilan hidup yang ada di sekitarnya.

Pembentuk yang berikutnya adalah intervensi pendidikan. Kesadaran budaya maritim bisa berubah manakala dilakukan terobosan di bidang pendidikan. Penulis pernah memetakan ada tiga model terobosan pendidikan pesantren: perubahan yang diinisiasi kiai/pengelola pesantren, perubahan 
yang digagas pemerintah dan perubahan yang digagas Lembaga Swadaya Masyarakat (LSM) (Murtadho, 2010).

Kasus pesantrenBisnis.com masih terkesan kurang kuat dalam mempunyai gagasan pesantren maritim. Hal ini ditandai dengan belum jelasnya konsep pengembangan pesantren maritim pada lembaga ini. Beberapa langkah bisa dilakukan, misalnya Bony Irawan mengusulkan tentang perlunya penguatan literasi kelautan (Irawan, 2018). Usaha yang lain, bisa juga dilakukan dengan pembukaan Sekolah Menengah Kejuruan (SMK) seperti pelayaran termasuk media efektif untuk mengubah perilaku masyarakat yang tadinya tidak menganggap laut sebagai kebutuhan dasar, dengan pendidikan kita disadarkan bahwa kita masih miskin kreativitas. Pesantren dengan gagasan pesantren maritim juga merupakan terobosan lain pendidikan yang bisa menghasilkan perubahan masyarakat yang berbudaya kemaritiman. Sekalipun dalam pelaksanaannya nanti akan berbagi konsentrasi antara pesantren sebagai tafaqquh fiddin dan pesantren dengan pengembangan ketrampilan maritim. Lebih jauh Prayitno dalam pendidikan kemaritiman perlu dikenalkan penggunaan metode Customer Relationship Management (CRM) yaitu optimalisasi penggunaan sosial media dalam peningkatan hubungan dan keterlibatan pelanggan dalam mengolah potensi kelautan (Prayitno, 2018).

Prasyarat ketiga, perubahan masyarakat menjadi masyarakat berkesadaran maritim juga bisa radikal manakala ada kehadiran investor terkait eksplorasi kelautan. Pada kasus Pesantren Bisnis.com usaha-usaha yang berkaitan dengan kelautan belum banyak dieksplorasi. Hal ini selain masih terbatasnya literasi tentang kelautan, juga komodifikasi kelautan masih rendah. Di daerah dengan latar belakang belum menjamin literasi maritim Tinggi (Irawan, 2019). Adanya fokus perhatian dan investasi yang cukup diharapkan bisa mengubah cara pandang peserta didik.

Dengan hadirnya investor yang mampu mengeksplorasi modal sosial yang dimiliki masing-masing di sebuah pesantren, maka perubahan perilaku bisa muncul di lembaga itu. Saat ini banyak investor di bidang kelautan yang mulai menggeliat seperti investasi pengembangan rumput laut, investasi pengembangan udang galah yang banyak hadir di daerah lampung. Kehadiran investor pada pesantren-pesantren di daerah nelayan akan sangat membantu dalam mewujudkan pesantren maritim.

Pengembangan budaya maritim di pesantren merupakan salah satu bentuk usaha mengubah kultur masyarakat melalui pendidikan. Dengan pendidikan, masyarakat pesantren dikenalkan dengan potensi laut sehingga santri lebih melek pada dunia kelautan. Pesantren bisa memilih di antara dua opsi: pertama, pesantren menjadikan ketrampilan kelautan sebagai program lifeskills tambahan di luar program tafaqquh fiddin sebagai karakteristik utama pesantren atau pilihan kedua, pesantren mengkhususkan diri dalam pengembangan lifeskills kelautan berkonteks pesantren.

Dalam implementasi program pengembangan pesantren maritim, sejauh ini Kementerian Agama nampaknya baru melakukan berbagai diskusi pembahasan awal. Belum banyak tindak lanjut yang kongkret di lapangan. Dari lapangan dirasakan masyarakat pesantren masih menunggu intervensi lebih kongkret dari Kementerian Agama dalam mewujudkan gagasan pesantren maritim ini.

\section{PENUTUP}

Sebagai akhir dari tulisan ini, peneliti menggaris bawahi beberapa kesimpulan yang bisa ditarik dari pertanyaan penelitian ini, dari kasus Pesantren Bisnis.com Istana Mulia Cinangka Serang, antara lain: Pertama, Konteks sejarah Banten menunjukkan bahwa daerah itu pernah mempunyai sejarah besar dalam tradisi kemaritiman, yaitu semasa keberadaan Kesultanan Banten. Saat itu Banten telah menjadi kota kosmopolitan dengan mengandalkan perdagangan berbasis maritim yang melibatkan berbagai negara asing seperti Arab, Portugis, Belanda. Tradisi besar kemaritiman Provinsi Banten nampaknya tidak terawat dengan baik dalam pengembangan di masyarakat, termasuk dalam pendidikan keagamaan di pesantren.

Kedua, respons pesantren di Banten terhadap gagasan pesantren maritim sampai saat ini masih minim. Pesantren yang mengusulkan 
diri menjadi pesantren maritim belum cukup memahami sepenuhnya konsep, arah dan orientasi apa yang dimaksud pengembangan pesantren maritim. Hal ini ada kaitannya dengan sejarah pendidikan Islam di Banten yang pernah energinya terkuras untuk kepentingan politik termasuk pengusiran penjajah dan setelah Indonesia merdeka pemerintah baru cenderung mengembangkan konsep pembangunan yang bersifat agraris.

Ketiga, pesantren masih menemukan kendala-kendala dalam membangun budaya maritim dalam sistem pendidikannya seperti terkait sistem teknologi dan informasi, sarana dan prasarana, sumber daya manusia, dan kondisi dunia maritim Indonesia

Keempat, beberapa langkah untuk mengembangkan pendidikan pesantren kemaritiman, perlu dipetakan permasalahan sekaligus poin-poin penting yang diharapkan membuat perubahan besar: a) memilih pesantren yang berdiri di tengah masyarakat dengan latar belakang kelautan; b) perlu dibuat terobosan pendidikan pesantren sebagai alternatif pendidikan kemaritiman; c) pendekatan investasi maritim di pesantren

Penelitian ini merekomendasikan langkah-langkah yang perlu dilakukan Kementerian Agama dalam mengembangkan pesantren maritim itu meliputi : Pertama, perlu segera disusun buku pedoman pengembangan pesantren maritim. Buku ini memperjelas konsep apa itu yang disebut pesantren maritim dan apa saja yang harus dilakukan pesantren maritim. Kedua, Kementerian Agama melakukan pemetaan pesantren yang potensial mengembangkan pesantren maritim. Lokasi pesantren yang berada di garis pantai akan menjadi ujung terdepan dalam pembangunan budaya maritim di Indonesia. Ketiga, Kementerian Agama perlu melakukan piloting pengembangan pesantren maritim untuk memperjelas capaian perubahan pendidikan keagamaan yang selaras dengan budaya maritim.

\section{UCAPAN TERIMAKASIH}

Atas selesainya penelitian ini, penulis merasa perlu mengucapkan rasa terima kasih kepada beberapa pihak yang telah menyukseskan jalannya penelitian ini. Pertama,
Pimpinan Puslitbang Pendidikan Agama dan Keagamaan yang telah memfasilitasi penulis dalam mendapatkan data di lapangan; kedua, pimpinan Kepala Wilayah Kementerian Agama Provinsi Banten yang telah memberikan referensi lembaga penelitian yang layak dijadikan sasaran penelitian; Ketiga, terima kasih juga kami sampaikan kepada pimpinan pesantren Bisnis.com Istana Mulia Serang Banten yang telah menerima dan memberikan data dan informasi terkait respons pesantren terhadap gagasan pesantren maritim.

\section{DAFTAR PUSTAKA}

Anggraeni, P. S. (2016) 'Politik Luar Negeri Indonesia Menuju Poros Maritim Dunia Di Era Pemerintahan Joko Widodo', eJournal Ilmu Hubungan Internasional, 4(2).

Darma, B. A. (2019) 'Pengembangan Ekonomi Berbasis Maritim Di Provinsi Banten', $J E Q u, 9(1)$, pp. 73-96.

Eko Yuri, Gunawan, D. and Barnas, R. (2018) 'Strategi Pangkalan TNI AL Banten Dalam Mendukung Pengamanan ALKI I', Jurnal Strategi, 4(2), pp. 71-88.

Graaf, de H. and Pigaud, T. (1989) KerajaanKerajaan Islam Di Jawa. Jakarta: Grafiti Press.

Horridge, A. (1986) Sailing Craft of Indonesia. Singapore: Oxford University Press.

Irawan, B. (2018) 'Framework Literasi Kelautan Sebagai Acuan Pembelajaran Sains di Negara Maritim', Pedagogi Hayati, 2(1), pp. 9-15.

Irawan, B. (2019) 'Profil Tingkat Literasi Kelautan Mahasiswa Pendidikan Biologi di Universitas Maritim Raja Ali Haji, Sebuah Studi Kasus Universitas Kemaritiman di Wilayah Kepulauan', in Talenta Conference Series: Science and Technology (ST). Medan: TALENTA. doi:

https://doi.org/10.32734/st.v2i2.519.

Kartodirjo, S. (1966) The Peasants' Revolt of Banten in 1888: Its Conditions, Course, and Sequel: A Case Study of Social Movements in Indonesia. Gravenhage: Martinus Nijhoff. 
Kila, S. (2018) 'Syekh Yusuf: Pahlawan Nasional Dua Bangsa Lintas Benua', Walasuji, 9(2), pp. 237-248.

Lombard, D. A. (2005) Nusa Jawa: Silang Budaya III-Warisan Kerajaan Konsentris. Jakarta: Gramedia Pustaka Utama.

Murtadho, M. (2010) 'Pesantren dan Pemberdayaan Ekonomi', Dialog, 30(63).

Muslimah (2017) 'Sejarah Masuknya Islam dan Pendidikan Islam Masa Kerajaan Banten Periode 1552-1935', Jurnal Studi Agama dan Masyarakat, 13(1), pp. 136-162.

Muzayini, A. (2010) Indahnya Berbisnis dengan Alloh SWT. Banten: Penerbit Fatihah Publishing.

Nainggolan, P. P. (2015) 'Kebijakan Poros Maritim Dunia Joko Widodo', Jurnal Politica Vol. 6 No. 2 Agustus 2015., 6(2)

Octavian, A. and Yulianto, B. A. (2014) 'Degradasi Kebudayaan Maritim: Sejarah, Identitas, dan Praktik Sosial Melaut Di Banten', Masyarakat Indonesia, 40(2), pp. 159-176.

Pianto, H. A. (2017) 'Keraton Demak Bintoro Membangun Tradisi Islam Maritim di Nusantara', Sosiohumaniora, 3(1). doi: 10.30738/sosio.v3i1.1521.

Prasetyo, H. (2016) Konsep Poros Maritim sebagai Paradigma Baru dalam Pembangunan Nasional. UUniversitas Malang.

Pratama, T. A. (2015) 'Kebijakan Poros Maritim Dunia Di Tengah Dinamika Asia Pasifik Saat Ini’, Paskas. Available at:

https://www.academia.edu/10062323.

Prayitno, O. T. (2018) 'Peningkatan Daya Saing Lembaga Pendidikan Kemaritiman di Era Masyarakat Ekonomi ASEAN dengan Penerapan CRM', IJIS, 1(1).

Pribadi, Y. (2017) 'Dinamika Hubungan Sosial Keagamaan Pada Masyarakat Nelayan Di Karangantu Banten', Teosofi, 7(1), pp. 199-224.

Reid, A. (2011) Asia Tenggara Dalam Kurun Niaga 1450-1680: Jaringan Perdagangan Global Jilid 2. Jakarta: Yayasan Obor Indonesia.

Republika.Co.Id (2015) 'Tujuan Kemenag Bangun Pesantren Maritim'. Available at:

http://khazanah.republika.co.id/berita/d unia-islam/islam-nusantara/.

Supriyono, A. (2013) 'Tinjauan Historis Jepara Sebagai Kerajaan Maritim Dan Kota Pelabuhan', Paramita, 23(1), pp. 27-39. doi:

https://doi.org/10.15294/paramita.v23i1 .2494

Susilowati, E. (2017) 'Etnis Maritim dan Permasalahannya', Sabda: Jurnal Kajian Kebudayaan, 7(1), pp. 1-18. doi: https://doi.org/10.14710/sabda.7.1.1 18.

Tahara, T. (2016a) Islam dan Budaya Kemaritiman di Sulawesi, Pengembangan Pendidikan Keagamaan (Pesantren) di Wilayah Maritim 29 Nop - 1 Des 2016 di Bantaeng Sulawesi Selatan. Jakarta: Puslitbang Pendidikan Agama dan Keagamaan.

Tahara, T. (2016b) 'Pelayaran Tradisional Orang Buton dan Kebijakan Poros Maritim Indonesia', Jurnal Masyarakat \& Budaya, 18(3).

Tahara, T. (2018) 'Nakodai Mara'dia Abanua Kaiyang Toilopi: Spirit Nilai Budaya Maritim Dan Identitas Orang Mandar', Walasuji, $\quad 9(2)$. doi: 10.36869/wjsb.v9i2.45.

Untoro, H. O. (2006) Kebesaran dan Tragedi Kota Banten. Jakarta: Yayasan Kota kita.

Yani, Y. M. and Montratama, I. (2015) 'Indonesia Sebagai Poros Maritim Dunia: Suatu Tinjauan Geopolitik', Jurnal Pertahanan \& Bela Negara, 5(2).

Yuliati (2014) 'Kejayaan Indonesia Sebagai Negara Maritim (Jalesveva Jayamahe)', Jurnal Pendidikan Pancasila dan Kewarganegaraan, 27(2), pp. 129-134. 
